\title{
CPD update: revised modular requirement
}

The October meeting of the Court of Electors agreed major changes in Continuing Professional Development (CPD) modular requirements, which will be phased in from 1 April 1999. These will reduce the number of hours required annually, and the modules themselves will be simplified. I hope that these changes will mean the clinicians who hitherto have felt that the existing modular requirements are too large or complex will now feel able to participate in our CPD scheme. Details will be set out in due course but they are described here in outline.

\section{Omission of formal modular require- ment for reading, research and per- sonal study (the present Module D)}

This will mean that the total number of hours required each year will be reduced from 150 to 50 hours. Reading/personal study of approximately 2 hours per week will still be recommended but not measured formally as a modular requirement.

\section{There will be two modular require- ments (total 50 hours) \\ External (20 hours)}

This will include both didactic teaching as well as participation in workshop type events (combining the present Modules A and B). Although there will no longer be a separate modular requirement for participatory learning, the paramount importance of this will be emphasised. This module is termed external because its essential component is attendance at events which involve speakers/workshop leaders from outside a clinician's own locality, sometimes but not necessarily at an 'away' venue.

\section{Internal (30 hours)}

This will include educational events (e.g. case conferences and audit meetings), participation in which is normally confined to staff dertved from one's own work locality (the present Module C).

\section{Adoption of a five-year cycle}

This will allow a moving average, thereby introducing a flexdbility in allowing for various types of leave that is difficult to achieve in the present one year cycle.

\section{Subscriptions}

A review is also currently being undertaken into the subscription arrangements, both with regards to CPD itself and its association with that for Advances in Psychiatric Treatment.

Gethin Morgan, Director of CPD, Royal College of Psychiatrists, 17 Belgrave Square, London SWIX 8PG

\section{Winter Meeting 1998}

The Winter Meeting was held at the Royal Lancaster Hotel, London on 20-23 January 1998.

\section{Business Meeting}

The Business Meeting was held on the 21 January 1998.

\section{Minutes}

The Minutes of the 1997 Winter Business Meeting held on the 22 January at the
Cardiff International Arena, Cardiff were approved.

\section{Election of Honorary Fellows}

The following were elected to the Honorary Fellowship: Professor James Griffith Edwards, Professor Hugh Freeman, Professor Alan Haworth, Professor Myrna Weissman, Dr Alistair Wright. 